\title{
ELECTRIC SHOCK INJURIES IN A HARRIS'S HAWK POPULATION
}

\author{
Author(s): James F. Dwyer
}

Source: Journal of Raptor Research, 40(3):193-199.

Published By: The Raptor Research Foundation

DOI: http://dx.doi.org/10.3356/0892-1016(2006)40[193:ESIIAH]2.0.CO;2

URL: http://www.bioone.org/doi/

full/10.3356/0892-1016\%282006\%2940\%5B193\%3AESIIAH\%5D2.0.CO

$\% 3 \mathrm{~B} 2$

BioOne (www.bioone.org) is a nonprofit, online aggregation of core research in the biological, ecological, and environmental sciences. BioOne provides a sustainable online platform for over 170 journals and books published by nonprofit societies, associations, museums, institutions, and presses.

Your use of this PDF, the BioOne Web site, and all posted and associated content indicates your acceptance of BioOne's Terms of Use, available at www.bioone.org/ page/terms_of_use.

Usage of BioOne content is strictly limited to personal, educational, and noncommercial use. Commercial inquiries or rights and permissions requests should be directed to the individual publisher as copyright holder. 


\title{
ELECTRIC SHOCK INJURIES IN A HARRIS'S HAWK POPULATION
}

\author{
JAMES F. DWYER ${ }^{1}$ \\ School of Natural Resources, University of Arizona, Tucson, AZ 85721
}

\begin{abstract}
Electrocution may be an important agent of mortality in many raptor populations, and has been implicated as a contributing factor in the endangerment of some species. In Tucson, Arizona U.S.A. the electrocution of Harris's Hawks (Parabuteo unicinctus) was reported in both the 1980s and 1990s. The latter report also described Harris's Hawks that survived electric shock injuries. From February 2003-May 2004, I captured and examined wild Harris's Hawks in Tucson to investigate whether electric shock injuries might be present in individuals that appeared healthy from a distance. I trapped 85 birds; seven exhibited definite electric-shock injuries, and seven exhibited suspected electric-shock injuries. One individual exhibited injuries not consistent with electric shock. I captured an equal number of males and females, but only one of the injured birds was a male. Females were significantly more likely to have injuries. Whether this difference reflects patterns of initial incurrence of injury, or of higher probability of survival after electric shock remains unresolved. As medium- and large-bodied raptors colonize urban areas where overhead electric systems tend to occur in high densities, those species may also incur increased risk of electrocution.
\end{abstract}

KeY WORDS: Harris's Hawk; Parabuteo unicinctus; electrocution; injury; urban.

\section{HERIDAS CAUSADAS POR DESCARGAS ELÉCTRICAS EN UNA POBLACIÓN DE PARABUTEO UNICINCTUS}

\begin{abstract}
Resumen.-La electrocución podría ser un agente de mortalidad importante en muchas poblaciones de rapaces, y se ha sugerido que es un factor que contribuye a que algunas especies se encuentren amenazadas. En Tucson, Arizona, Estados Unidos, la electrocución de individuos de la especie Parabuteo unicinctus fue documentada en las décadas de 1980 y 1990. Los informes más recientes también indicaron que algunos individuos sobrevivieron a las heridas causadas por las descargas eléctricas. Entre febrero de 2003 y mayo de 2004, capturé y examiné individuos silvestres de esta especie en Tucson para investigar si individuos aparentemente sanos podrían presentar heridas causadas por descargas eléctricas. Capturé 85 aves, de las cuales siete definitivamente presentaron heridas asociadas con descargas eléctricas y siete presentaron heridas que podrían haber tenido esta causa. Uno de los individuos presentó heridas que no fueron causadas por descargas. Capturé un número igual de machos y hembras, pero sólo una de las aves heridas era macho. Las hembras fueron significativamente más propensas a presentar heridas que los machos. No está claro si esta diferencia refleja los patrones iniciales de ocurrencia de las heridas, o diferencias en la probabilidad de supervivencia posterior a las descargas. A medida que las aves rapaces de tamaño mediano y grande colonizan áreas urbanas en donde los sistemas eléctricos elevados tienden a encontrarse en altas densidades, estas especies pueden también hacerse más propensas a la electrocución.
\end{abstract}

[Traducción del equipo editorial]

The electrocution of raptors has been an ongoing conservation concern for decades (Olendorff et al. 1981, Ferrer et al. 1991, Real et al. 2001), and electrocution incidents continue to be reported from around the globe (R. Lehman unpubl. data). Electrocution has been suggested as an important agent

\footnotetext{
${ }^{1}$ Present address: Virginia Polytechnical Institute and State University, Dept. of Fisheries and Wildlife Sciences, 106 Cheatham Hall, Blacksburg, VA 24061 U.S.A.; email address: biojimmi@yahoo.com
}

of mortality in many raptor species and populations (Franson and Little 1996, Gil-Sanchez et al. 2004, Rubolini et al. 2005), and cited as a contributing factor in the endangerment of some species (Donazar et al. 2002, Ontiveros et al. 2004, Sergio et al. 2004).

In Tucson, Arizona, the electrocution of Harris's Hawks (Parabuteo unicinctus) was reported by Whaley (1986) (eight killed), and by Dawson and Mannan (1994; at least 57 killed). Dawson and Mannan (1994) also reported finding Harris's Hawks that 
had received an electric shock, but were not killed immediately (at least nine instances). These individuals were incapable of flight, were captured on the ground by hand, and were euthanized.

Recommended treatments for electric shock injuries in raptors can be found in veterinary medical journals (e.g., Burke et al. 2002) and texts (e.g., Cooper 1978, Fraser et al. 1991, Hass 1993). If some raptors are shocked, critically injured, and require euthanasia, while others presumably survive with treatment, then a continuum of electric shock injuries may exist. Personnel investigating the electrocution of raptors in the field typically seek evidence of incidents by searching for carcasses at the bases of utility poles (Manosa 2001, Harness 2002, Pearson et al. 2002), or along power-line right-of-ways (Ferrer et al. 1991, Guyonne 2000). These methods reduce the likelihood that an ambulatory raptor suffering from an electric shock injury would be detected, if one were present. Thus, a general sense among researchers seems to have arisen that most incidents of electric shock are fatal.

Alternatively, it is possible that some raptors survive in the wild with chronic symptoms or physical evidence of electric shock. Because Tucson harbors a particularly dense raptor population (Mannan et al. 2000) and because previous research had suggested that hawks in this area were at high risk of electrocution, I captured seemingly healthy, wild Harris's Hawks in Tucson, Arizona, and examined them for evidence of electric-shock injury.

I define "electrocution" as occurring when a bird is killed immediately upon serving as a path for electric current. A bird that serves as a path for electric current, but is not killed immediately, has suffered an electric shock. I hypothesize that electric shock may on some occasions lead to temporary or permanent injury, rather than always result in death.

\section{METHODS}

Between 1 February 2003 and 31 March 2004, I captured Harris's Hawks in urban Tucson, Arizona. The Tucson metropolitan area encompasses approximately $1000 \mathrm{~km}^{2}$, and includes a population of about 900000 people (Population Planning Committee 2004). The overhead electric power system in Tucson consists of approximately 100000 utility poles (J. Sheehey, Tucson Electric Power Company, pers. comm.). Of these, roughly $10 \%$ and $80 \%$ are $4-\mathrm{kV}$ and $8-\mathrm{kV}$ distribution poles, respectively, and roughly $10 \%$ are $\geq 69-\mathrm{kV}$ transmission structures (exact figures are proprietary; Tucson Electric Power Company, unpubl. data).

I located Harris's Hawks by driving in the vicinity of known territories, and captured birds with a bal-chatri trap (Bloom 1987) baited with a wild-caught white-throated woodrat (Neotoma albigula). Trapping occurred from $30 \mathrm{~min}$ before sunrise until at least $2 \mathrm{hr}$ after sunrise. I offered the trap immediately to the first Harris's Hawk detected without any a priori attempt made to assess the sex, age, health, or band status of the targeted bird. The trap remained set until at least one bird was captured, the target bird moved away, or 30 min elapsed with the trap in full view of a bird, which did not attack.

Captured Harris's Hawks were weighed (to determine sex; Dawson and Mannan 1994), aged by plumage (Wheeler and Clark 1999), banded, examined for evidence of electric-shock or other injuries, photographed, and released. I classified birds with a mix of juvenile and adult plumage as second-year, and birds in complete adult plumage as after-second-year.

I captured four individuals whose masses were intermediate between published diagnostic parameters for Harris's Hawks in Tucson (male $<800 \mathrm{~g}$, female $>900 \mathrm{~g}$; Dawson and Mannan 1994). Three of these birds with a mass of $\geq 849$ g I classified female, one at $827 \mathrm{~g}$ I classified male. One injured bird, which was a male by mass $(767.5 \mathrm{~g})$, had a tarsus diameter too large for a 7A band, and was classified as an underweight female.

Physical examinations involved a close visual inspection of the feet and lower legs, especially the toe pad of the foot and between the toes. Proper articulation of the joints was assessed by moving each portion of each lower leg through the normal range of motion. Wings were similarly examined, and I focused particular attention on the skin and coverts of the carpal area, and on proper extension of the wing. Each remige and rectrice was examined individually for fault bars, breakage, or charring. Feathers with fault bars, or feathers missing due to normal molt (no scarring around epidermis at insertion point), or broken during normal wear (no charring present), were not considered injuries. The contour feathers of the body and head were also examined. To assess proper articulation of the neck, I held unhooded birds upright, and facing me with my hand holding the upper legs, lower body, and wing tips. This grasp prevented all movement, except movement of the head and neck. From this position, I pivoted my wrist to rotate the bird along its vertical axis. If the bird pivoted its head and neck to maintain eye contact with me, I concluded that head and neck injuries were absent.

Descriptions of electrocution injuries in raptors most often involve burns to the feet, legs, wings, or flight feathers (Cooper and Eley 1979, Hass 1993, Burke et al. 2002) that should result in uniquely identifiable patterns of injury in survivors. If these patterns were present and the injury site was charred, I classified the bird as exhibiting an electric-shock injury. If the same patterns were present, but charring was absent, I classified the bird as exhibiting a suspected electric-shock injury. Injuries which did not fit either category were classified as cause unknown.

I used $t$-tests to evaluate the statistical significance of differences between means, and chi-square tests to evaluate the statistical significance of differences between proportions. I report one-tailed distributions for $P$.

\section{RESULTS}

I captured 85 Harris's Hawks; $49.4 \%$ were male, and $50.6 \%$ female (Table 1). Fifteen Harris's Hawks (17.6\%) exhibited evidence of injuries (Appendix). 
Table 1. Sex, age, injury type, and mass of Harris's Hawks captured in Tucson, Arizona from February 2003March 2004.

\begin{tabular}{|c|c|c|c|c|c|c|c|c|c|}
\hline \multirow{3}{*}{$\begin{array}{l}\text { SEX } \\
\text { AgE }\end{array}$} & \multirow{3}{*}{$\begin{array}{c}\text { NUMBER } \\
\text { UNINJURED }\end{array}$} & \multicolumn{3}{|c|}{ Number InJuRED } & \multirow[b]{3}{*}{ TOTAL } & \multirow{2}{*}{\multicolumn{2}{|c|}{ Average Mass (g) }} & \multirow{2}{*}{\multicolumn{2}{|c|}{ Mass By InJURY }} \\
\hline & & \multirow{2}{*}{$\begin{array}{c}\text { CONFIRMED } \\
\text { ELECTRIC- } \\
\text { SHOCK INJURY }\end{array}$} & \multirow{2}{*}{$\begin{array}{c}\text { SUSPECTED } \\
\text { ELECTRIC- } \\
\text { SHOCK INJURY }\end{array}$} & \multirow{2}{*}{$\begin{array}{l}\text { UNKNOWN } \\
\text { INJURY }\end{array}$} & & & & & \\
\hline & & & & & & UNINJURED & INJURED & $t$ & $P^{4}$ \\
\hline \multicolumn{10}{|l|}{ Male } \\
\hline $\mathrm{HY}^{1}$ & 15 & 0 & 0 & 0 & 15 & 684.88 & $\mathrm{~N} / \mathrm{A}$ & $\mathrm{N} / \mathrm{A}$ & $\mathrm{N} / \mathrm{A}$ \\
\hline $\mathrm{SY}^{2}$ & 12 & 1 & 0 & 0 & 13 & 687.86 & 727.3 & $\mathrm{~N} / \mathrm{A}$ & $\mathrm{N} / \mathrm{A}$ \\
\hline $\mathrm{ASY}^{3}$ & 14 & 0 & 0 & 0 & 14 & 679.05 & $\mathrm{~N} / \mathrm{A}$ & $\mathrm{N} / \mathrm{A}$ & $\mathrm{N} / \mathrm{A}$ \\
\hline \multicolumn{10}{|l|}{ Female } \\
\hline HY & 7 & 2 & 2 & 0 & 11 & 942.16 & 868.85 & 1.780 & 0.053 \\
\hline SY & 8 & 3 & 1 & 0 & 12 & 1020.93 & 1010.78 & 0.307 & 0.373 \\
\hline ASY & 14 & 1 & 4 & 1 & 20 & 1055.13 & 1019.20 & 0.803 & 0.217 \\
\hline Total & 70 & 7 & 7 & 1 & 85 & & & & \\
\hline
\end{tabular}

$1 \mathrm{HY}=$ Hatch-year.

$2 \mathrm{SY}=$ Second year.

${ }^{3}$ ASY $=$ After second year.

4 1-tailed $P$-value.

Seven of these birds were classified as electric-shock victims (Figs. 1-2), and seven were identified as suspected 8-kV electric-shock victims (Fig. 3). One bird exhibited injuries not consistent with electric shock. Harris's Hawks in the Tucson area rarely range beyond $0.8 \mathrm{~km}$ from their nests during the breeding season (Dawson and Mannan 1991). The injuries depicted in Figs. 1-2 occurred during breeding seasons at nests surrounded by at least a $5 \mathrm{~km}$ radius of $8-\mathrm{kV}$ overhead electric power. Thus, I suggest that

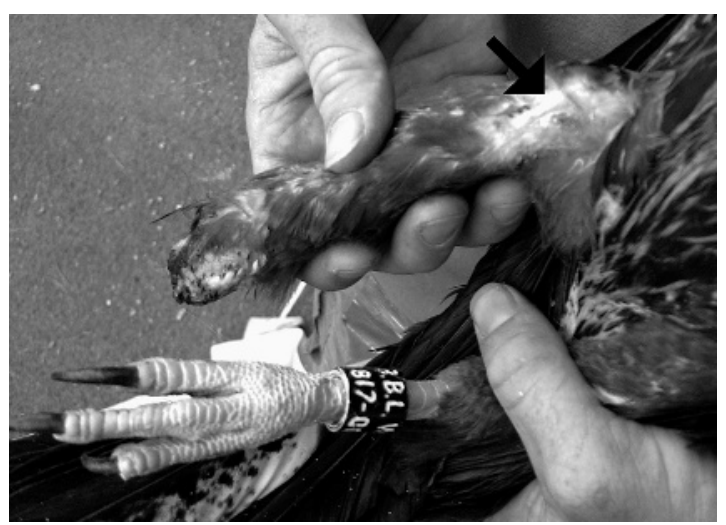

Figure 1. An 8-kV electric-shock injury to a hatch-year (3 wk post-fledging) female Harris's Hawk captured 7 August 2003 in Tucson, AZ. Note charring around the amputation point at the distal end of the tibia, paired with an entry/exit wound at proximal end of the tibia. the injuries depicted are the result of contact with an 8-kV distribution system.

There was no difference in the time it took to capture injured versus uninjured individuals from time after sunrise $(t=0.330$, df $=83, P=0.371$; two afternoon captures excluded) or from the time the trap was set $(t=0.683$, df $=85, P=0.2482)$. Nor did I find any significant pattern in the presence of injuries by age $\left(\chi^{2}=0.330\right.$, df $=2, P=$ 0.9851 ; Table 1).

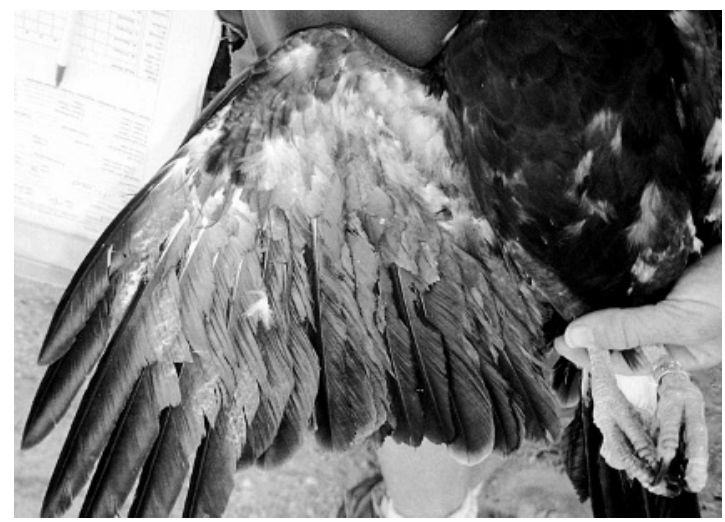

Figure 2. An 8-kV electric-shock injury to an after-second-year (adult) female Harris's Hawk captured 29 August 2003 in Tucson, AZ. Note extensive charring of the remiges and coverts of the right wing. The tail was similarly burned (not depicted). 


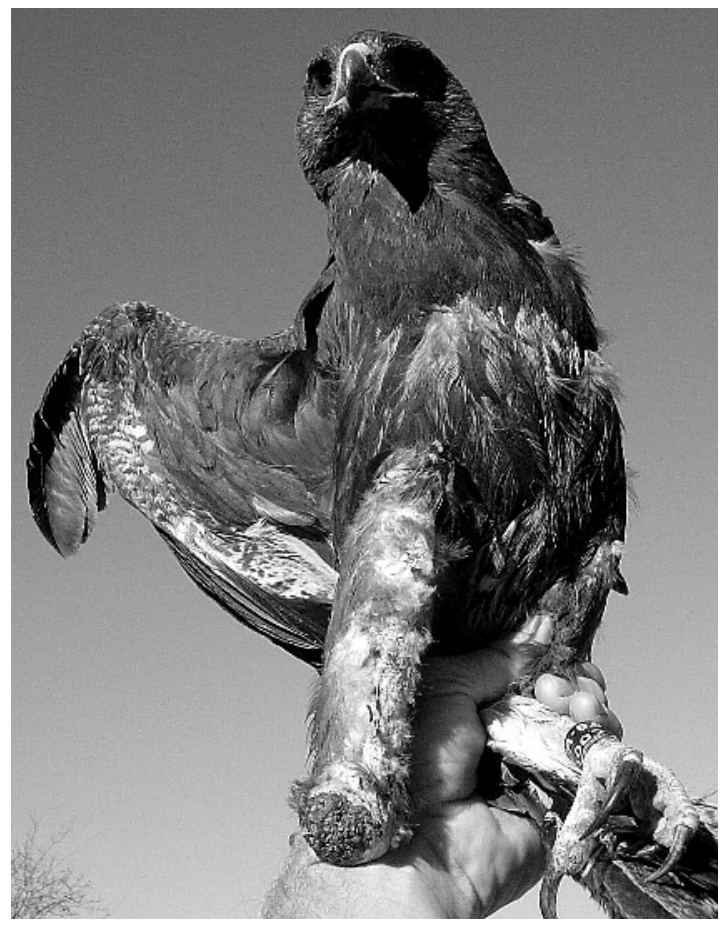

Figure 3. An 8-kV electric-shock injury to the right leg of a hatch-year female Harris's Hawk captured 29 March 2004. This is the same individual pictured in Figure 1. Note that the thickly scarred amputation point on the right leg no longer exhibits charring.

Of the 85 birds trapped, $2 \%$ of the males and $31 \%$ of the females exhibited signs of electric-shock injury. Captured females were more likely to be suffering from chronic injuries than males $\left(\chi^{2}=\right.$ 13.3 , df $=1, P<0.001)$. Injured females had consistently, but not significantly, lower masses than healthy females (all females of all age classes combined, including recaptures: $t=1.51, \mathrm{df}=43, P=$ 0.070; all females excluding recaptures: $t=1.50, \mathrm{df}$ $=41, P=0.071$; individual age classes, Table 1 ).

Two individuals that exhibited charred tissues at the time of their first capture were recaptured during my study (Appendix). When recaptured, I noted scar tissue present on both birds, and classified them as suffering from suspected electric-shock injuries. Later, when I reviewed my banding records I found that the scar tissue I recorded had replaced previously-charred tissue. These observations support the criteria I used to classify suspected electric-shock injuries.

\section{DISCUSSION}

Previous studies of Harris's Hawks have consistently found trapping to be biased toward males (Bednarz 1995). I found a slight trapping bias toward females, but I also found individuals that were intermediate between published reports of mass in my study area. This suggests body mass is an imperfect discriminator of sex in Harris's Hawks, at least in the Tucson area. Future researchers should use alternate morphometrics, behavioral observations or molecular analyses to verify the sex of captured individuals.

I found a relatively high proportion $(17.6 \%)$ of injuries in the Harris's Hawks I captured. However, it is possible that my sample is not representative of the Harris's Hawk population in the Tucson area. Injured females tended to have lower masses than uninjured females, indicating that they may have been food-stressed; it is possible that these birds were more likely than healthy females to be attracted to the potential prey in the bal-chatri trap and captured.

Many of the injuries I describe here appear to be the result of electric shocks. Why or how some birds might survive an electric shock is unknown. Studies evaluating the mechanics of electrocution and electric shock in humans indicate that electrical current causes universal stimulation of the nervous system and universal stimulation and contracture of the musculature, including the heart, for as long as current flows through the body. When current flow ceases, all muscles including the heart relax, and death occurs as a result of cardiopulmonary arrest, and subsequent oxygen deprivation (Koumbourlis 2002). In humans, if thermal trauma has not damaged the heart, a blow to the chest can reinitiate contractions. Assuming that electric current operates in birds as it does in humans, I suggest that occasionally a raptor that has received an electrical shock falls to the ground in such a way that the impact reinitiates cardiac operation.

In humans, when electric current passes through only the limbs and not through the central nervous system, limbs or limb function can be lost without associated cardiac arrest (DeBono 1999, Davidson et al. 2001). A similar phenomenon may occur in raptors, and result in some of the injuries I describe. The relative low occurrence of these scenarios may explain why most raptors are likely to be killed immediately upon receiving an electric shock.

Because Harris's Hawks in the population I studied are nonmigratory and social (Bednarz 1995), 
individuals may be more likely to persist with chronic injuries than members of other populations or species. Nonmigratory birds probably exhibit limited dispersal (i.e., do not move out of the area), and group-mates may allow individuals which cannot hunt for themselves to feed on kills. Harris's Hawk groups in Tucson commonly nest twice and occasionally three times in one year, and occupied nests have been found in every month of the year (Bednarz 1995). Nestlings, fledglings, and breeding females are typically provisioned by group-mates (Bednarz 1995). Given these patterns, extension of normal provisioning behavior to support injured individuals of groups is possible. That male Harris's Hawks provision females regularly, while the inverse has not been documented, suggests that a male suffering from a chronic injury may beless likely to survive an electric-shock injury. This may explain why more female Harris's Hawks seemingly survived electric- shock injuries than males.

Sex may be an important predictor of survival with a chronic injury. Also, a bird's sex may be an important risk factor to incurring an electric shock. Because female Harris's Hawks are larger, they are more likely to simultaneously contact two differentially-energized conductors and thus serve as a path for electric current (Ferrer and Hiraldo 1992). Differences in detection of chronic injuries by sex may reflect either a difference in survivorship of any injury type, or in the occurrence of electric-shock injuries. The potential for increased risk of electric contact during prey exchanges near the nest should be considered in future efforts to investigate and mitigate the electrocution of raptors.

It is possible that at least some of the injuries reported herein resulted from factors other than electric shock. Regardless of the cause, the effect of chronic injuries on raptors is unknown. Even minor changes in wing shape, wing loading, or the profile of a flying bird can handicap aerial performance in passerines (Norberg 1995, Kullberg et al. 1996, Hedenstrom 2002). Raptors are likely to be similarly affected. Individuals with damaged or missing flight surfaces may have trouble maneuvering to capture prey or to defend against enemies or competitors. Individuals missing portions of a lower limb are clearly handicapped in terms of capturing or restraining prey. Survival and fecundity may be affected in turn. In my sample, females with injuries seemed to have lower mass than females without injuries. This suggests some cost of chronic injury (i.e., a diversion of resources into survival and away from reproduction).

The injuries I report are unlikely to be detected during some typical population assessments (e.g., roadside surveys or counts of migrants), because birds recorded via these methods are often seen only briefly and at long distances. Injuries, if present, are more likely to be identified during banding operations, and personnel working with raptors and other large birds should document injuries in the animals they handle.

The number of Harris's Hawk nesting territories detected in urban Tucson has increased from about 10 in 1975 (W. Mader pers. comm.), to 22-26 annually from 1984 to 1986 (Dawson and Mannan 1991), to at least 55-60 in 2003 and 2004 (J. Dwyer and R. Mannan, unpubl. data). It is likely that much of the urban habitat the Tucson population is colonizing is dangerous because of the presence of an extensive overhead electrical power system. Harris's Hawks are not unique among raptors in their recent colonization of urban and other humanmodified habitats. Love and Bird (2000) compiled reports of over 25 species of falcons, hawks, and owls breeding in urban habitats. Langgemach (2002) and Millsap et al. (2004) report similar patterns for eagles.

Assuming most of the injuries I reported were the result of electric shocks, then biologists could be underestimating the total impact of overhead-electric systems on raptor populations. This is especially true in urban areas where overheaddistribution systems tend to be dense. Sergio et al. (2004) noted that there has been little investigation of the population level effects of the electrocution of raptors. When such studies are undertaken, care should be taken to consider the possibility of chronic injuries in the population and to incorporate that factor into population level analyses.

\section{ACKNOWLEDGMENTS}

This work was conducted in partnership with Tucson Electric Power Company (TEP), which responded quickly to incidents of raptor-electric contact by modifying dangerous poles. I thank John Swift for his help in finding and trapping hawks, and R.W. Mannan, Bob Lehman, Jennifer O. Coulson, Lisa Ellis, Brandon Rheude, and one anonymous reviewer for their readings of manuscripts. Funding for this project was provided by TEP, and by the Arizona Game and Fish Department, Heritage Fund Grant No. U03003. 


\section{Literature Cited}

Bednarz, J.C. 1995. Harris's Hawk (Parabuteo unicinctus). In A. Poole and F. Gill [EDs.], The birds of North America, No. 146. The Academy of Natural Sciences, Philadelphia, PA and the American Ornithologists' Union, Washington, DC U.S.A.

Bloom, P.H. 1987. Capturing and handling raptors. Pages 99-123 in B.A. Giron Pendleton, B.A. Millsap, K.W. Cline and D.M. Bird [EDS.], Raptor management techniques manual. Natl. Wildl. Fed., Washington, DC U.S.A.

Burke, H.E., S.E. Swaim, And T. Amalsadyala. 2002. Review of wound management in raptors. J. Avian Med. Surg. 16:180-191.

CoOpER, J.E. 1978. Veterinary aspects of captive birds of prey. The Standfast Press, Saul, Gloucestershire, U.K.

AND J.T. ELEY. 1979. First aid and care of wild birds. David and Charles Inc., North Pomfret, VT U.S.A

Davidson, J., S. Champion, R. Cousins, And L. Jones. 2001. Rehabilitation of a quadruple amputee subsequent to electrical burns sustained whilst hang gliding. Disabil. Rehabil. 23:90-95.

Dawson, J.W. AND R.W. Mannan. 1991. The role of territoriality in the social organization of Harris' Hawks. Auk 108:661-672.

_ AND 1994. The ecology of Harris's Hawks in urban environments. Final report submitted to Arizona Game and Fish Department.

DeBono, R. 1999. A histological analysis of a high voltage electric current injury to an upper limb. Burns 25: 541-547.

Donazar, J.A., C.J. Palacios, L. Gangoso, O. Ceballos, M.J. Gonzalez, and F. Hiraldo. 2002. Conservation status and limiting factors in the endangered population of Egyptian Vulture (Neophron percnopterus) in the Canary Islands. Biol. Conserv. 107:89-97.

Ferrer, M., M. Delariva, and J. Castroviejo. 1991. Electrocution of raptors on power-lines in southwestern Spain. J. Field Ornithol. 62:181-190.

—_ AND F. HiRALDO. 1992. Man-induced sex-biased mortality in the Spanish Imperial Eagle. Biol. Conserv. 60:57-60.

Franson, J.C. And S.E. LitTLE. 1996. Diagnostic findings in 132 Great-horned Owls. J. Raptor Res. 30:1-6.

Fraser, C.M., J.A. Bergeron, A. Mays, And S.E. Aiello. [EDS.]. 1991. The Merck veterinary manual; a handbook of diagnosis, therapy, and disease prevention and control for the veterinarian, $7^{\text {th }}$ Ed. Merck \& Company, Inc., Rahway, NJ U.S.A.

Gil-Sanchez, J.M., M. Moleon, M. Otero, and J. Bautista. 2004. A nine-year study of successful breeding in a Bonelli's Eagle population in southeast Spain: a basis for conservation. Biol. Conserv. 118:685-694.

GuYONNE, F.E.J. 2000. Avian mortality from power lines: a morphologic approach of a species-specific mortality. Biol. Conserv. 95:353-359.
HARNESS, R.E. 2002. Effectively retrofitting power lines to reduce raptor mortality. Pages 29-45 in R.G. Carlton [ED.], Avian interactions with utility and communication structures; proceedings of a workshop held in Charleston, SC. December 2-3, 1999. Electric Power Research Institute Technical Report No. 1006907, Palo Alto, CA U.S.A.

HAss, D. 1993. Clinical signs and treatment of large birds injured by electrocution. Pages 180-183 in P.T. Redig, J.E. Cooper, J.D. Remple, and D.B. Hunter [EDS.], Raptor biomedicine. University of Minnesota Press, Minneapolis, MN U.S.A.

Hedenstrom, A. 2002. Aerodynamics, evolution and ecology of avian flight. Trends Ecol. Evol. 17:415-422.

Koumbourlis, A.C. 2002. Electrical injuries. Crit. Care Med. 30 (supplement): S424-S430.

Kullberg, C., T. Fransson, and S. Jakobsson. 1996. Impaired predator evasion in fat blackcaps (Sylvia atricapilla). Proc. R. Soc. Lond. B. Biol. Sci. 263:1671-1675.

LangGemach, T. 2002. The White-tailed Eagle in the state of Brandenburg and in Berlin, Germany - status and conservation. Corax 19:23-36.

LOve, O.P. AND D.M. BIRD. 2000. Raptors in urban landscapes: a review and future concerns. Pages 425-434 in R.D. Chancellor and B.-U. Meyburg [EDS.], Raptors at risk: proceedings of the $\mathrm{V}$ world conference on birds of prey and owls. World Working Group on Birds of Prey and Owls, Berlin, Germany.

Mannan, R.W., C.W. Boal, W.J. Burroughs, J.W. Dawson, T.S. EstabROOK, AND W.S. RichARDSON. 2000. Nest sites of five raptor species along an urban gradient. Pages 447-453 in R.D. Chancellor and B.-U. Meyburg [EDS.], Raptors at risk: proceedings of the $\mathrm{V}$ world conference on birds of prey and owls. World Working Group on Birds of Prey and Owls, Berlin, Germany.

Manosa, S. 2001. Strategies to identify dangerous electricity pylons for birds. Biodivers. Conserv. 10:1997-2012.

Millsap, B., T. Breen, E. McConnell, T. Steffer, L. PhilLIPS, N. Douglass, and S. TAYlor. 2004. Comparative fecundity and survival of Bald Eagles fledged from suburban and rural natal areas in Florida. J. Wildl. Manage. 68:1018-1031.

Norberg, U.M. 1995. How a long tail and changes in mass and wing shape affect the cost of flight in animals. Funct. Ecol. 9:48-54.

OlendorfF, R.R., A.D. Miller, AND R.N. Lehman. 1981. Suggested practices for raptor protection on powerlines: the state of the art in 1981. Raptor Research Report 4.

Ontiveros, D., J. Real, J. Balbontin, M.R. Carrete, E. Ferreiro, M. Ferrer, S. Manosa, J.M. Plequezuelos, AND J.A. SAnChez-Zapata. 2004. Conservation biology of the Bonelli's Eagle in Spain: research and management. Ardeola 51:461-470.

Pearson, D.C., C.G. Thelander, and M. Morrison. 2002. Assessing raptor electrocution on power lines. Pages 105-124 in R.G. Carlton [ED.], Avian interactions with 
utility and communication structures; proceedings of a workshop held in Charleston, SC. December 2-3, 1999. Electric Power Research Institute Technical Report No. 1006907, Palo Alto, CA U.S.A.

Population Planning Committee. 2004. Population estimates and projections. Pima Association of Governments. http://www.pagnet.org/Population/Data/default.htm (last accessed 8 August 2004).

Real, J., J.M. Grande, S. Manosa, and J.A. Sanchez-Zapata. 2001. Causes of death in different areas for Bonelli's Eagle (Hieraaetus fasciatus) in Spain. Bird Study 48: 221-228.

Rubolini, D., M. Gustin, G. Bogliani, and R. Garavaglia. 2005. Birds and powerlines in Italy: an assessment. Bird Conserv. Int. 15:131-145.
Sergio, F., L. Marchesi, P. Pedrini, M. Ferrer, and V. Penteriani. 2004. Electrocution alters the distribution and density of a top predator, the Eagle Owl (Bubo bubo). J. Appl. Ecol. 41:836-845.

Whaley, W.H. 1986. Population ecology of the Harris' Hawk in Arizona. Raptor Res. 20:1-15.

WheEler, B.K. AND W.S. Clark. 1999. A photographic guide to North American raptors. Academic Press Ltd., San Diego, CA U.S.A.

Received 19 November 2004; accepted 12 July 2006 Associate Editor: James C. Bednarz

Appendix. Descriptions of injured Harris's Hawks captured in Tucson, Arizona from February 2003 through March 2004. Class: ESI = confirmed electric shock injury, ESI? = possible electric shock injury, RCP $=$ recapture, UNK $=$ injury characteristics inconclusive. Sex: $\mathrm{F}=$ female, $\mathrm{M}=$ male. Age: $\mathrm{HY}=$ hatch year, $\mathrm{SY}=$ second year, ASY $=$ after second year.

\begin{tabular}{|c|c|c|c|c|c|}
\hline ID & INJURY CLASS & SEX & AGE & Mass (g) & InJuRy DETaILS \\
\hline 1 & ESI & M & SY & 727.3 & $\begin{array}{l}\text { Open wound with charred edges on left halux, electrical petechiae on } \\
\text { left tarsus }\end{array}$ \\
\hline 2 & ESI & $\mathrm{F}$ & HY & 885.8 & $\begin{array}{l}\text { Left wing tip charred, left primaries No. } 9 \text { and No. } 10 \text { absent (First } \\
\text { captured } 26 \text { August 2003) }\end{array}$ \\
\hline 3 & ESI & $\mathrm{F}$ & HY & 903.8 & $\begin{array}{l}\text { Right foot and tarsometatarsus absent, tibiotarsus charred, exuding } \\
\text { fluid, scarred proximally (Fig. 1; First captured } 7 \text { August 2003) }\end{array}$ \\
\hline 4 & ESI & $\mathrm{F}$ & SY & 918.3 & $\begin{array}{l}8 \text { primaries, } 6 \text { secondaries, and associated coverts charred on right } \\
\text { wing, } 8 \text { rectrices charred (Fig. 2) }\end{array}$ \\
\hline 5 & ESI & $\mathrm{F}$ & ASY & 1064.0 & $\begin{array}{l}\text { Right tarsometatarsus charred at midpoint, right foot swollen, unable } \\
\text { to close }\end{array}$ \\
\hline 6 & ESI & $\mathrm{F}$ & SY & 1068.5 & $\begin{array}{l}\text { Face singed above beak, left foot split and charred between outer and } \\
\text { center toes }\end{array}$ \\
\hline 7 & ESI & $\mathrm{F}$ & SY & 1076.7 & $\begin{array}{l}\text { Left wing tip charred, primary No. } 4 \text { singed, left outer talon deformed } \\
\text { and undersized }\end{array}$ \\
\hline 8 & ESI? & $\mathrm{F}$ & HY & 767.5 & $\begin{array}{l}\text { Right alula scabbed, ragged, necrotic, largest alula feather and } \\
\text { associated coverts absent }\end{array}$ \\
\hline 9 & ESI? & $\mathrm{F}$ & HY & 918.3 & $\begin{array}{l}\text { Left outer toe swollen, split, edge of split and underlying tissue black, } \\
\text { necrotic }\end{array}$ \\
\hline 10 & ESI? & $\mathrm{F}$ & ASY & 945.7 & $\begin{array}{l}\text { Right wing missing ventral marginal coverts proximal to alula, right } \\
\text { outer talon chipped }\end{array}$ \\
\hline 11 & ESI? & $\mathrm{F}$ & ASY & 946.9 & $\begin{array}{l}\text { Right halux absent, wound on left outer toe, underlying tissue } \\
\text { necrotic }\end{array}$ \\
\hline 12 & ESI? & $\mathrm{F}$ & SY & 979.6 & Skin of right foot appeared charred, but was unbroken \\
\hline 13 & ESI? & $\mathrm{F}$ & ASY & 1052.4 & Left center toe absent at second joint \\
\hline 14 & ESI? & $\mathrm{F}$ & ASY & 1105.2 & Tail and left outer toe absent \\
\hline 2 & RCP & $\mathrm{F}$ & SY & 951.0 & $\begin{array}{l}\text { Left wing tip heavily scarred, primaries No. } 9 \text { and No. } 10 \text { poorly } \\
\text { developed (Recaptured } 14 \text { February 2004) }\end{array}$ \\
\hline 3 & RCP & $\mathrm{F}$ & SY & 1037.6 & $\begin{array}{l}\text { Right foot and tarsometatarsus absent (Fig. 3; Recaptured } 29 \text { March } \\
\text { 2004) }\end{array}$ \\
\hline 15 & UNK & $\mathrm{F}$ & ASY & 1001.0 & Pieces of skin on right middle toe excised, edges ragged, no charring \\
\hline
\end{tabular}

